\title{
The Impact of Competencies, Information Search, and Competitive Strategy on the Export Performance
}

\author{
Lena Elitan \\ Widya Mandala Catholic University Surabaya - Indonesia
}

\begin{tabular}{l|l}
\hline A R T I C L E I N F O & A B S T R A C T \\
\hline $\begin{array}{l}\text { Received: December 06, 2010 } \\
\text { Final revision: March 20, 2011 }\end{array}$ & $\begin{array}{l}\text { This confirmatory study is aimed at analyzing the impact of } \\
\text { relationships, information search, and competencies on competitive } \\
\text { Seywords: } \\
\text { Small and medium enterprises, } \\
\text { export performance, } \\
\text { growth and profitability }\end{array}$ \\
samples that obtained through mailed questionnaires. The results \\
show: Firstly, the perception of information, information sources, and \\
export competence has no significant effect on competitive strategy. \\
However the findings for SMEs in Indonesia, indicated that export \\
related information has negative effects on competitive strategy. \\
Secondly, export competencies has an enormous influence on the \\
company's capacity and ability to use information appropriately, when \\
the company must deal with challenges or when the company is \\
eager to take advantage of the opportunities to increase growth and \\
profitability. Thirdly, competitive strategy does not directly affect export \\
performance but it is moderated by the environment uncertainty. It \\
indicates that the influence of competitive strategy would be greater \\
in an uncertain business environment. The uncertain business \\
environment will encourage companies to explore competitive \\
strategy to improve their performance.
\end{tabular}

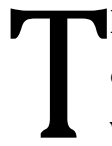
he contribution of small and medium enterprises (SMEs) to Indonesia's export volume in 2009 reached Rp. 151 trillion.

With that achievement, 7.7 million workers were employed it absorbed 70 percent of national workforce. It is expected that in 2010 the export volume would double the previous figure as priority and attention are given to the development of SMEs. Despite their substantial contribution to promote the national economy in the form of creation of at least 3.4 million business units, SMEs have not been able to compete with large-scale company. 
Compared with other countries, Indonesia's export of creative products is less competitive because the products produced by small and medium industries have not been able to meet the demand of the export market. The government is aware of this discouraging condition, which may be due to the basic technology used by SMEs. In addition this industries are not well developed across the country. Another obstacle is the fact that SMEs are unprepared to compete with others in the free market because many do not hold produc certification which is increasingly necessary. The implementation of free trade also becomes a threa to domestic industry.

An increasingly competitive global competition requires companies to have a competitive advantage in order to win and gain market and opportunities. Global business competition encourages industrie to create cost efficiency and product differentiation, while the global corporate competition arises as a result of transnational companies' efforts to develop business by the construction of new plants, a joint venture with the host country, and industria relocation. This condition leads to increasingly strong competition between global companies and domestic companies and there has been concern that it will capture the domestic market. To anticipate this challange, domestic enterprises need to develop a competitive strategy that focuse on core competencies in terms of price, quality, flexibility, and delivery.

The role of small and medium industries or enterprises is inevitably important in the world economy. Small and medium enterprises (SMEs) have been exposed to business competition and business environment which show the importance of competitive strategy for their export performance so that they can compete or deal directly with large companies. In this condition, the performance of SMEs is largely determined by their competitive strategies which are supported by the ability to obtain and manage information in the market. Proper search of export-related information and use of sources of information will be helpful in finding ways to develop and consolidate the activities of SMEs overseas and to see other companies which have the desire and potential to improve and profit from information.

Some empirical evidence suggests that information search has an important impact on export performance of SMEs. Seringhaus (1993) provides a framework for explaining how information search affects SMEs' export performance. The research model is based on the assumption that the use of information sources, export expertise, and research in the field of marketing has a direct impact on business performance. Skills associated with information focus on overseas market segmentation, marketing research represents the type of information sought, and performance is measured by the share of exports as percentage of the total sales. Test results indicate significant relationship between "expertise" and performance, but without the use of information sources and information search.

Denis and Depelteau (1985) examined the impact of the use of information resources on export expansion and diversification. They divided the samples into two groups, depending on whether each is a new or experienced exporter. Three performance levels were defined for each group's performance: low, medium, and high. Performance is measured by the rate of export growth in the past five years. The result of this study shows that "fair trade" has a strong impact, but some sources are found to be less important. Kleinschmidt and Ross (1986) studied the relationship between the SMEs' use of information, information resources, and export performance in high-technology sector. The finding also indicates that there is no clear indication as to the relationship between information search and information sources.

Boutary (1998) as cited in Julien and Ramangalahy (2003) examined the impact of information processing on performance. The result indicates the importance of management but it only provides little information about the impact of information processing. The researcher shows that the success of SMEs in export is not information and environment sensitive, and more likely to focus on managing internal information and on customer satisfaction or market needs. Three recent studies examined SMEs' export performance based on several factors included in information search. First, Cavusgil (1984) tested the exporting companies' market research based on the degree of internationalization. Successful exporters consider information search more important and use a wider range of sources of information. Second, Samiee, Walters, and Dubois (1993) compared the use of proactive (innovative) and reactive use of information sources by exporters. They find that proactive exporters use more second sources of information and have a wider range of sources of information. Third, Houle (1994) as cited in Julien and Ramangalahy (2003) compared the knowledge and use of market information and sources of information based on the level of involvement of foreign companies. They found that a successful exporter is more knowledgable about international markets and uses both information and relevant sources of information

Contradictory or different findings in the results of empirical studies on the impact of relationships and information search and competencies on SMEs' competitive strategy and performance have encouraged the researcher to conduct a confirmatory study to test hypotheses and various research issues related to the findings by using a different research setting: small and medium enterprises (SMEs) in Indonesia. The selection of SMEs as a setting is based on the premise that the paradigm of economic development in Indonesia which was originally oriented towards largescale industrial growth has shifted to economic development with more emphasis on people's economy (small and medium industries).

The shift in paradigm provides opportunities for the growth and development of new and more productive economic activities and is a challenge for all involved in the competition. Based on the condition of small and medium industries in Indonesia, the study was conducted to test the impact of search of export-related information and export competence on SMEs' competitive strategy and export performance. Hence, we can find out whether the research model is still relevant when applied to a different research setting, i.e a largescale manufacturing company in Indonesia.

Based on the illustration of the issues previously, described, the study aims to answer the following questions:

Does export-related information affect SMEs competitive strategy?

2. Do the sources of information affect SMEs competitive strategy?

3. Do SMEs' export competencies affect the adopted competitive strategy?

4. Does SME's competitive strategy affect thei performance?

5. Does the uncertainty in business environment moderate the influence of competitive strategy on export performance?

\section{The Role of Small and Medium Enterprise (SMEs)} About $20 \%$ small and medium enterprises (SMEs) plan to expand abroad in the next two years. This is revealed in a survey entitled HSBC Global Smal Business Confidence Monitor which captured the views of small-sized business players toward global business and economic prospects. More and more SMEs are eager to develop business abroad, including SMEs in Indonesia. It is the response to the dynamics of today's economy, and it provides a new perspective in free trade, after the ACFTA had been made effective. Inter-regional free trade agreement which began in January 2010 has effectively eliminated tariff and it will certainly affect business players, including SMEs (okezone.com, 2010).

Small and Medium Enterprises (SMEs) is an important component which supports economic 
progress in Indonesia, as evidenced by the issuance of Instruction of President of the Republic of Indonesia No. 10 in 1999 on the Empowerment of Small and Medium Enterprises. Through this Instruction, the government is seeking to improve small and medium enterprises into a strong, independent, and superior entity. The Instruction provides criteria used to classify a business as a medium-sized enterprise: that is the owner has a ne worth between Rp. 200,000,000 to Rp. 10 billion and that net worth does not include land and buildings as a place of business.

The industrial sector contributed to $30 \%$ of the total Gross Domestic Product (GDP) and it got highe and almost reached 30\% during the period 2004 2007. Of the total contribution, the non oil-and-gas industry sector was a major contributor with the total average of contribution of $80 \%$ in the same period. Based on the data from Central Statistic Agency (BPS), the role of sub-sector industries such as foods, beverages and tobacco; textiles, leathe goods and footwears; fertilizers, chemicals an rubber goods; and transport equipment, machinery and tools, reached $80 \%$ of the total contribution of the national non oil-and-gas industries.

The data on the growth of processing sector showe an average performance of $5 \%$ (2004-2007) and the growth of non oil-and-gas industry reached about $6 \%$ in the same period. The agriculture and husbandry industries, and the oil and gas industrie showed a decreasing trend when compared with the pre and post crisis period at the average of $13 \%$ (1994-1996) far exceeding the growth afte the crisis (an average of 5\% during 1999-2006). This is certainly a major concern in the formulation of strategies for national industrial development.

The formulation of macroeconomic policy and the limitation in the use of technology are the main focus in the strategy for development of small and medium industries. The technology use focuses on the issue of low standardization for the quality of products that makes it difficult to meet the criteria of international markets and the low added value in finished products. The concept of total quality management has been applied since 16 years (up to 2007) to the national industry, especially to SMEs, but it is still less optimal. It is because the formation of 3.833 clusters in 3.417 SMEs over a period of 16 years is considered far from proportional compared with the number of SMEs in Indonesia which reaches 3.5 million units across 400 districts / cities. This phenomenon highlights the fact that the contribution of SMEs to Gross Domestic Product (GDP) by industry sector was only $38 \%$, or much lower than the contribution of large industries which reached $62 \%$.

\section{Obstacles in Export Faced by Small and Medium} Enterprises

Basically, Indonesian SMEs have a fairly good prospect and great potential to develop along with the increasing role of SMEs in non-oil exports over the years. The role of SMEs in non-oil exports increased to Rp 75.45 trillion or 19.4 percent of total national exports in 2000 , and to $\mathrm{Rp} 75,86$ trillion, or 19.9 percent of total national exports in 2003. That increase is supported by the export of SMEs' non oil-and-gas products including products of agriculture, plantation, fishery, textiles and garments, furniture, products of processing industry, and works of art. However, SMEs role in exports is still relatively small because SMEs face many obstacles in their export activities, leaving the SMEs's products to be exported by big players or large-scale exporters that can reduce or even eliminate the obstacles. The government's support is certainly needed through a supportive and easily implemented policy.

Tambunan (2003) classified export-oriented SMEs into two groups, namely, Manufacturer-Exporter (Direct Exporter) and Indirect Exporter. Direct exporters produce export products and sell them directly to buyers or importers overseas, while Indirect Exporters produce products for export, but do not export them directly to buyers/importers. They use domestic export agencies or exporters.
Manufacturer-Exporter SMEs tend to earn higher profits than Indirect Exporter SMEs do.

SMEs that play a significant role are those that rely on the production of hand-made products, such as jewelry and wood carving, as they tend to be labor intensive. This characteristic is an advantage for SMEs, as they rely more on handcrafting skills. Largescale enterprises that tend to be capital intensive would be difficult to enter this business. This proves the important role of SMEs in employment, especially in the times of economic crisis. SMEs' primary export destination is Singapore, although from the perspective export commodities, the destinations are relatively diverse. The high volume of exports to Singapore suggests that there is still a potential for increased added value or economic rent of SMEs to the exported products, if they are directly exported to the countries of main consumers. Singapore is a transit, so the products exported to Singapore will be re-exported to other countries.

Some SMEs decide to be more export oriented or not to be influenced by key factors such as export trading and financing problems. Export trading problems are due to the high risk of export activities (both the risks in payment or delivery of goods), a grace period of payment, and the high cost of exports. Meanwhile, the financing problems are due to SMEs' limited capital, and problems related to financing and guaranteeing institutions, for instance, their minimum support to SMEs in financing and guaranting exports. This makes the SMEs' marketing strategy tend to wait for buyers, creating a trading mechanism commonly called as the buyer's market.

Hardono (2003) suggests that principally SMEs have some classic barriers, i.e barriers associated with low quality of human resources (HR), lack of business management, low access to sources of financing and markets, as well as the lack of information and technology. SMEs face business barriers and limitations in export which are classified into two categories: internal and external.
The internal barriers are those inherent in the SMEs, while external barriers are those caused by externa factors not inherent in the SMEs.

Some internal barriers in export activities include low commitment in fulfilling customers' orders, both locally and internationally, the less optima management system applied by SMEs, especially in terms of production, administration, and finance the limited facilities and infrastructure owned by SMEs to fulfill orders; low quality of human resources, leading to business management not based on rational considerations; limited capital, particularly working capital, poor communication and information networks with relevant parties, such as in the purchase of raw materials, as sometimes SMEs have only limited resources, so goods are obtained at higher prices; low capacity in research and development, thus not being able to fulfill the wishes of the buyers optimally.

Meanwhile, the external barriers facing SME include: unstable supply and prices of raw materials and other supporting materials; highe requirements from buyers, such as those related to product quality, quality of social environment quality of work environment, competitive rates, being environmentally friendly, some government's regulations which are less conducive and lead to slower rate of SMEs' exports; low access to markets, including product demand, produc quality standards, timely delivery, and price competition; low access to sources of financing including information about credit scheme and the high interest rate; the emergence of hidden costs associated with transportation, customs, and security; difficulty in meeting the procedures and a relatively long period required to patent SMEs products.

The government's political decisions in all aspects and levels to address the complex issues of SME need various approaches to successfully remove the existing barriers. The policy aims to provide a greater opportunity to SMEs to reduce or lower 
the barriers. The approach should be adopted to remove problems SMEs face in their export activities and it can be developed by improving SMEs financial and managerial capabilities, building a network to market the export products, and enhancing the promotion of export products. Conducive government's policies / regulations will be the key to success in reducing barriers in export activities.

Competitive Strategy and Improvement of Performance of Small Medium Enterprise

To compete in an environment full of uncertainty and intense competition, SMEs need a competitive strategy to ensure their survival. Two main factors that can affect their ability to survive in this globa crisis are a high local content in production inputs and flexibility in the adjustment of production capacity. The advantage in the form of high local content in production inputs means it can produce a commodity with a certain uniqueness and distinctiveness to create an added value to products to be more competitive in the marke. However, most SMEs still rely on the local market and domestic demand as their main source of turnover except on certain products. They are less innovative and already quite satisfied with what they have earned. These are the factors that make their products not very competitive.

Rapid changes in demands in the market during the crisis were responded by SMEs without the great inefficiency. The studies of CESS and The Asia Foundation (2002) about medium and large scale industries shows that the smaller the scale, the smaller the impact of output reduction caused by the crisis. Flexibility in the adjustmen of production capacity is also a factor that makes effects of reduced output on small and medium scale businesses remains small. SMEs can become a safety valve for economy in the supply of labor, manufacture of outputs, livelihood and source of peace for Indonesians. The very basic reasons that can explain why they survive are: their economic activities were not connected with loans in dollars; they cut expenses by substituting expensive inputs with the cheaper ones; they did business diversification and opened new markets; and the vast majority of SMEs basically used their own capital, not loans.

CESS and Swisscontact (2003) conducted a study of SMEs' exports in Bali and the results showed that the competitiveness of exporters' / trading houses' products which were from SMEs sharply declined because they could not compete with products from countries where the production costs were cheaper. The increasingly competitive market conditions, less supportive business environment and increasing costs were also found to trouble the exporters / trading houses.

The main strategy that can be adopted to improve the performance and the role of Indonesian SMEs in free market and to overcome the existing gap is to develop strong medium-sized enterprises within the structure of industry in Indonesia. The past and current experiences indicate that the policy for the development of large-scale business (realized in the form of Law on Limited Liability Company) and the development of small-scale business (realized in the form of Law on Small Business) is clearer and more focused, while the medium-sized enterprises are left to develop on their own. The placement of medium-sized business in terms of policy and provision of relevant information tend to be biased.

Empirical studies in the industrial sector (which illustrate the real competition) show that the medium-sized business has several advantages when competing in the market. Productivity per worker in small and medium industries outperforms even productivity in large industries. Medium industries are also better able to anticipate market changes than large industries do. It is this factor that causes the former relatively more stable in facing the crisis although it still relies heavily on domestic demands for its turnover. If we look at the existing composition of small and medium industries, the food industry, textile and apparel industries as well as industry of materials from timber are the preferred medium-sized industries. We can also see that with the industry can compete in the global market.

The potential and ability to carry out innovations based on skills, mastery of technology, human resources and capital accumulation of mediumsized enterprises are better than those of small businesses. Similarly, their ability to access markets, information and funding are too. In addition, flexibility in responding the market enables the medium-sized enterprise to be tougher to survive than large businesses are. Thus, in the context of free competition, it is necessary to promote medium-sized enterprises by improving efficiency and innovation and encouraging competitiveness.

It is true that the role of SMEs in exports is less dominant than that of small businesses. However, with the position and strategic role they play, their advantage can be optimized. Medium-sized enterprises deserve to be promoted as a motor which supports SMEs in free competition because their potential in terms of technology and human resources is much higher than that of the small and micro enterprises. Efficiency is a must considering changes in the order of world market especially in the countries of export destinations of Indonesian products (Europe, USA and Japan) which face increasingly hard barriers due to political and security reasons. Not only does Indonesia face that condition, but it also has to compete with China which threatens the export market as well as the domestic market.

\section{Conceptual Framework}

The previously conducted studies are generally conceptual, not based on a conceptual framework that helps to understand the relationship between information search and performance. In terms of findings, the results provide little confidence and evidence which focuses on the direct or indirect impact of information search on SMEs' export performance. To overcome the limitations, this study will first outline the theoretical framework and then explain the concepts used to describe the relationship or connection between research variables in ways that are different from those used by previous researchers.

Conceptually, this research is based on the premise that underlies globalization, which suggests that the ability to master information and knowledge is an important factor in explaining the competitive advantage and corporate performance. This includes two important issues in resource-based view including: 1) the company's competitive strategies that affect corporate performance, 2) the fact that information and sources of information are a strategic resource for generating competitive advantages. According to this theory, information networks, and competence are major determinants of a company's competitive advantage.

In connection with the findings of the previou studies, this study aims to find a relationship between export performance, competitive strategy, and information search which is then divided into three sections called the source of information, information search, and export competence. The search of export-related information is expected to help develop and consolidate the SMEs' activities in developing business overseas. It is also expected that the information is used to study how other companies with similar desire and potential expand their business in international setting to improve and earn benefits from information search. A research model in this study is illustrated in Figure 1.

\section{Information Search, Information Sources}

\section{and Export Competencies}

Perception of the importance of export- related information and information sources has become a focus of most empirical studies. Seringhaus (1987) as cited in Julien and Ramangalahy (2003) distinguishes between target and experiental information and concludes that dependence on target information will reduce as more experience is gained. Several recent empirical studies 


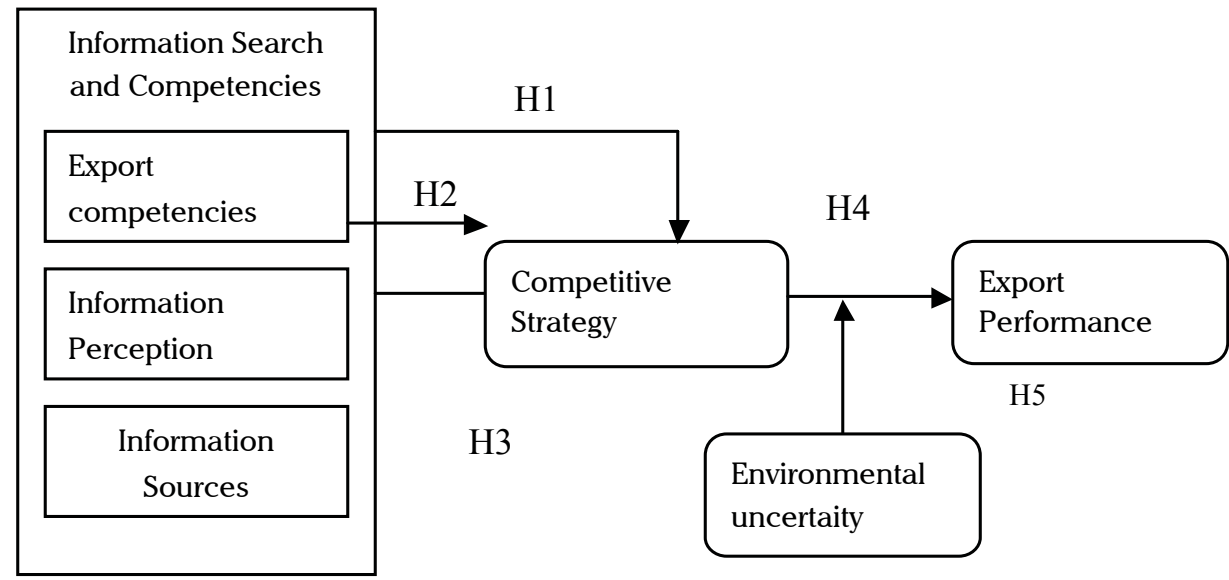

Figure 1. Research Model

showed that the most important information for exporting SMEs is about overseas markets (the size, potential, structure, trends, emergent markets and entry modes), consumers (the demands and needs, consumer behaviors, preferences, habits), competition (the strategies, strengths and weaknesses, products offered and price), products (the need for adaptation, technical norms, innovations), price (the levels, trends, modes of payment, and margins), promotion (the methods and opportunities), distribution (the cost, channel, intermediaries performance), and the general environment (the barriers to export, political and economic background).

Hypothesis 1: Export-related information affects export competitive strategy.

According to the literature, exporting SMEs meet their needs by using several different sources. Frequency of use of information sources becomes the focus of empirical research. Studies mention that the most important source (the most commonly used) is the one related to overseas markets and distribution (the consumers, agents and representatives, retailers, exporting companies), supply interfaces (the bankers and suppliers), industrial sector (the reviews and specialized journals, other companies, and industrial associations), institutional environment (the government offices and publications), internal private, public databases, and internet). sources (the databases, employees, sales, branches, overseas mission), and electronic sources (the

Hypothesis 2: Sources of export-related information affect export competitive strategy.

Export competencies (export experience and expertise) have an important role in explaining the capacity of SMEs in using important information and sources of information and also their involvement in export activities. Seringhaus (1993) as cited in Julien and Ramangalahy (2003) argues that the export competencies have an enormous influence on the company's capacity and ability to use information appropriately, when the company must face challenges or wants to benefit from the opportunities to enhance growth and profitability. Results of the research also show that the greater the competence of information, the higher the SMEs' performance of. Some competencies a company may have, according to the literature, include international, international marketing competence, marketing expertise, and knowledge and skills in export.

Hypothesis 3: SMEs' export competencies affect their competitive strategy

\section{Export Performance}

The concept of SMEs' export performance is a subject of much controversy. Many measuring criteria have been proposed in the literature. Kaynak, 1992, and Bijmolt and Zwart, 1994, argue that the range of SMEs' performance measurement criteria clearly suggests a multidimensional concept. Export intensity (export sales as a percentage of the total sales) and growth rate of export ratio often use the criteria from the literature, because they are relatively easy to collect. Kleinschmidt (1985) as cited in Julien and Ramangalahy (2003) have supported export intensity measurements for several years and introduces export intensity measurements by incorporating other indicators which are not correlated with export intensity, such as the perception of successful exports or profitability.

Madsen (1987) as cited in Julien and Ramangalahy (2003) argues that some literature reviews classify performance criteria into four groups, namely export profitability (the amount of profits or the perceived export profitability compared with the domestic sales), export volume (the export absolute value or export as percentage of the total sales), export growth (the percentage or absolute value of export growth), and various other indicators (perception of success, the variability of export). Similarly, Denis (1990) as cited in Julien and Ramangalahy (2003) identifies two approaches for measuring performance: a quantitative one based on the measurement of volume of export and a qualitative one based on various criteria that measure perception of success in overseas markets such as reputation as an international company.

\section{Competitive Strategy}

Based on implicit empirical studies which use a generic strategy as proposed by Porter (1980), Namiki (1988) as cited in Julien and Ramangalahy (2003) concludes that exporting SMEs generally adopt four types of competitive strategies. First, marketing differentiation based on competitive pricing, brand development, control over distribution, advertising, and innovation in the context of marketing techniques. Second, segmentation differentiation based on the ability to offer specialty products to specific consumer groups. Third, innovation differentiation based on the ability to offer new products and superior products. Fourth, product services based on quality of products and services provided to consumers. The results of previous studie indicate that good performance of SMEs is related to the growth of export and profitability, adoption of segmentation differentiation or innovation differentiation strategy.

Hypothesis 4: Competitive strategy affects SMEs export performance

Conceptual and empirical literature provides some evidence about the influence of environmental dynamism on the choice of competitive strategy. Competing in a rapidly changing environmen indicated by the increasingly shorter life cycle of a product, with better informed consumers, rapid diffusion of technology, customized products, and the improving new competitors require companies to establish competitive strategies in order increase their flexibility and productivity. Environmental uncertainty is identified as an important contingency in the conceptual and empirical studies in competitive strategy and manufacturing strategy (Skinner, 1969; Hofer, 1975 Van Dierdonck and Miller, 1980). This study shows that the environmental dynamism will support the decision of options of competitive strategies.

Hypothesis H5. Environmental uncertainty moderate the impact of competitive strategy on performance.

\section{METHODS}

\section{Population and Sample}

The purpose of this study is to analyze the impact of relationships between information search and competencies and competitive strategy and the performance of Indonesian SMEs. The population made the object of the study includes small and medium enterprises in Indonesia. They are SME which are registered with the Statistics Directory published by the Central Bureau of Statistics (BPS), in 2004. Samples were determined using the 
purposive sampling technique, and the selected sample was a manufacturing company with the criteria saying that it has a large scale, too. The number of samples used in this study was 100 SMEs. The classification of small, medium and large companies for the study was done based on the number of permanent workers employed: (1) Small companies: 10-99 employees. (2) Medium companies: 100-499 employees. (3) Large companies: 500 employees or more.

\section{Data Collection Techniques}

The data used in this study include primary data and secondary data. The primary data were obtained through questionnaires which were mailed to SMEs, with their managers as the target subject. The distribution of questionnaires was conducted for one month with a deadline for return in four weeks. To increase the rate of return of the questionnaires, the researcher, adopting the suggestion proposed by Issac and Michael (1990), used a SASE and followup mailings for the secondary data associated with collection of data pertaining to existing SMEs in Indonesia.

\section{Operational Definitions}

The five-point Likert scale was used to measure the company's level of excellence of as compared with its competitors on the statement specified in the items of the questionnaire. Constructions tested in this study include:

1. Export Competencies

Export competencies in this study represent export experience and each of their own expertise that has an important role in explaining the capacity of SMEs to exploit important information and information sources and also the involvement in export activities. Some competencies of the company according to the literature include international competence, international marketing competence, marketing expertise, and knowledge and skills in exports.

2. Perception of Information

Perception of information in this study indicates that the important information for exporting
SMEs is about overseas markets, consumers, competition, products, promotion price, distribution, and general environment.

3. Sources of Information

Sources of information in this study include some of the most important sources related to overseas markets and distribution, supply interface, the industrial sector, institutional environment, resources, and electronic sources.

4. Competitive Strategy

Competitive strategy in this study represents four types of exporting SMEs' competitive strategies generally adopted by SMEs: marketing differentiation, segmentation differentiation, innovation differentiation, and product service.

5. Environmental uncertainty

In this study the uncertainty of business environment is identified as an important contingency in conceptual and empirical studies in both competitive strategy and manufacturing strategy (Skinner, 1969; Hofer, 1975; Van Dierdonck and Miller, 1980), which is measured by ten items according to th eexisting literature.

6. Export Performance

In this study export performance is measured based on performance criteria which are classified into four groups: the export profitability, export volume, export growth, and various, other indicators such as perception and variability of export success.

\section{Validity and Reliability Tests}

Testing the validity and reliability of an instrument was conducted even though the instrument used was adopted and modified from the existing literature. An instrument is considered to possess high reliability if the value of Chronbach's Alpha is higher than 0.6 (Nunnaly, 1978). In addition, an additional test was carried out to see the reliability of the instrument by calculating the coefficient of homogeneity. Homogeneity coefficient is the correlation between individual items and the total score of all items. The higher the coefficient, the

Table 1. Chronbach Alpha and item Homogeneity for All Variables

\begin{tabular}{lcccc}
\hline \multicolumn{1}{c}{ Variable } & $\begin{array}{c}\text { Number } \\
\text { of items }\end{array}$ & $\begin{array}{c}\text { Number of items } \\
\text { issued }\end{array}$ & $\begin{array}{c}\text { Cronbach } \\
\text { Alpha }\end{array}$ & Item homogeneity \\
\hline Perception of Information & 21 & 0 & .9128 & $.363-.729$ \\
\hline Sources of Information & 22 & 0 & .9403 & $.456-.877$ \\
\hline Export Competencies & 20 & 0 & .8715 & $.449-.624$ \\
\hline Competitive Strategy & 13 & 0 & .7894 & $.361-.806$ \\
\hline Environmental uncertainty & 10 & 0 & .6095 & \\
\hline Performance of SMEs & 4 & 0 & .7946 & $.353-.869$ \\
\hline
\end{tabular}

more reliable the instrument. If the correlation between individual items and the total score is not significant, the item is not valid.

The test results of the reliability and validity of the instrument are presented in Table 1 The results of this study demonstrate the reliability of the instrument which is proved to be acceptable because all items have high reliability and validity. Cronbach'a alpha for all instruments to measure each variable ranges from 0.6095 to 0.9403 . Judging from the the coefficient of homogeneity, all are significant at alpha .01. It shows that all items used in this study are reliable and valid.

\section{Analysis Techniques}

\section{Simple Linear Regression Analysis}

Linear regression analysis is a statistical analysis method which uses a specific mathematical model consisting of several assumptions. In theory, it is clear that the results of linear regression analysis will have a (valid) value only if all the assumptions used are acceptable. Therefore, all the assumptions to be used should be tested to test the validity of the model. It uses the following work pattern in linear regression analysis. Simple Linear Regression can be formulated as follows:

$$
\mathrm{Y}=\mathrm{a}+\mathrm{bX}
$$

The equation shows that an independent variable (Y) is a linear function of the dependent variable

(X). The constant a and slope $\mathrm{b}$ are called the coefficients of regression. Constant a is a linear function that intersects the $Y$ axis, which is at the estimated value of $Y$ when $X=0$.

\section{Multiple Linear Regression Analysis}

Pratisto (2004) argues that regression analysis is useful for predicting how far the influence of one or several independent variables $(\mathrm{X})$ on the dependen variable (Y). Simple linear regression only discusse the relationship between one independent variable with a single dependent variable, whereas multiple linear regressions discuss the relationship between one dependent variable with several independent variables. A multiple linear regression has the general form expressed as follows:

$$
Y=a+b_{1} X_{1}+b_{2} X_{2}+b_{3} X_{3}+\ldots \ldots \ldots .+b_{n} X_{n}
$$

\section{Hierarchical Regression}

To test the influence of the relationship between independent variables and dependent variables, a hierarchical regression model is used. The moderating impact can be seen on the significance of interaction terms. The interaction term will be known whether the moderator variable is a positive or negative moderator.

\section{RESULTS AND DISCUSSION}

\section{Characteristics of Respondents}

A total of 350 questionnaires were sent to manufacturing companies in Indonesia. Of the 350 questionnaires sent via air mail, 23 companies have changed address or bankrupt. A total of 
questionnaires returned were 45 questionnaires: 9 could not be used in data processing due to incomplete or it was not filled. The total numbe of questionnaires which were returned and ready to be processed were 36 questionnaires. The response rate was 10.28 per cent.

The characteristics and profiles of respondents show that thirty six exporting companies participated in this study. The majority of respondents in this study have been operating for more than 30 years, so they are export-oriented companies. Only about 4 percent of respondents are newly established

Table 2.1. Samples and Rate of Retum

\begin{tabular}{lr}
\hline Total questionnaires sent & 350 \\
\hline Companies changed an address or dissolved & 23 \\
\hline Total of questionnaires returned & 45 \\
\hline Total of questionnaires that cannot be processed & 9 \\
\hline Total of questionnaires that were processed & 36 \\
\hline The rate of return based on the number of questionnaires which were & $36 / 350 \times 100 \%=10,28 \%$
\end{tabular}

The rate of return based on the number of questionnaires which were

$36 / 350 \times 100 \%=10,28 \%$

processed

Source: Processed data

Table 2.2. Samples and Rate of Return

\begin{tabular}{lrr}
\hline & Mean & Standard Deviation \\
\hline Information about market prices & 2.4722 & 1.13354 \\
\hline Information about potential products & 2.7222 & 1.36510 \\
\hline Information about new products & 2.8056 & 1.21466 \\
\hline Information about consumers' tastes and needs & 1.5833 & .84092 \\
\hline Information about methods of promotion & 2.0278 & 1.02779 \\
\hline Information about methods of market penetration & 2.4167 & 1.27335 \\
\hline Information about strengths of competitors & 2.4444 & 1.10698 \\
\hline Information about weaknesses of competitors & 2.6389 & 1.22247 \\
\hline Information about competitors' competitive strategies & 2.3889 & 1.12828 \\
\hline Information about methods of distribution & 2.3611 & 1.09942 \\
\hline Information about export standards and regulations & 2.3333 & 1.19523 \\
\hline Information about export license & 2.6944 & 1.21466 \\
\hline Information about potential customers & 2.5278 & 1.20679 \\
\hline Information about contact persons and business associates & 3.5278 & 1.02779 \\
\hline Information about development of business relations & 3.6389 & .89929 \\
\hline Information about methods of contract payment & 3.6389 & 1.01848 \\
\hline Information about transportation options & 3.2222 & .95950 \\
\hline Information about commission & 4.0278 & .65405 \\
\hline Information about customs and excise & 3.7778 & .63746 \\
\hline Information about international trade & 3.6389 & .89929 \\
\hline Information about government's assistance and regulations & 3.5833 & .93732 \\
\hline Level of importance of perception of information & 2.8796 & .64428 \\
\hline
\end{tabular}

companies. The distribution of participants by fields of business is fairly balanced ranging from those in the textile, clothing and leather to high technology. Seventy-two percent of the participating SMEs are locally owned and the rest are foreign-owned or cooperate with international entities. The distribution of export destinations include countries like Japan, Hongkong, Taiwan, Korea, ASEAN countries, USA, Australia and European countries.

\section{Descriptive Statistics}

Tables 2.2. - 2.7. show the average response of respondents to each of variables in this study. Based on Table 2.2, it can be concluded that for the variable of perception of information, five items of statements considered important viewed from

Table 2.3. Samples and Rate of Return

\begin{tabular}{lrr}
\hline & Mean & Standard Deviation \\
\hline Information from customers & 3.1944 & .92023 \\
\hline Information from representatives or branches & 3.1667 & .77460 \\
\hline Information from agents, wholesalers, distributors & 3.1111 & .74748 \\
\hline Information from sales branch offices & 3.0278 & 1.02779 \\
\hline Information from parent company & 3.5278 & .90982 \\
\hline Information from suppliers & 3.3889 & .90326 \\
\hline Information from business associates & 3.4444 & .96937 \\
\hline Information from competitors & 3.0556 & 1.06756 \\
\hline Information from business associations & 3.4444 & .84327 \\
\hline Information from region-based business associations & 3.3056 & .98036 \\
\hline Information from international trade & 3.4444 & 1.02663 \\
\hline Information from trade groups & 3.4722 & 1.02779 \\
\hline Information from international marketing agencies & 3.4722 & .77408 \\
\hline Information from financial institutions & 3.5833 & .93732 \\
\hline Information from local stakeholders & 3.6111 & .90326 \\
\hline Information from foreign government organizations & 3.2778 & .91374 \\
\hline Information from standardization agencies & 3.8056 & .78629 \\
\hline Information from international consultants & 3.4167 & .93732 \\
\hline Information from special business journals & 3.7778 & .92924 \\
\hline Information from internet & 3.3333 & 1.04198 \\
\hline Information from newspapers, television, radio & 3.4722 & .87786 \\
\hline Information from government's statistical data & 3.2222 & 1.04502 \\
\hline Intensity of sources of information & 3.3889 & .61901 \\
\hline
\end{tabular}

the average value given by the respondents are information about commission (4.0278), informatio about the customs and excise (3.7447), information about government's assistance and regulations (3.7778), information about the development of business relationships (3.6389), and information about methods of contract payment (3.6389), and information about international trade (3.5957).

Based on Table 2.3. it can be concluded that for the variable of sources of information, five item of statements considered important viewed from the mean value given by the respondents are the information from standardization agencies (3.8056), information from local stakeholders and information from special business journals (3.7778), information from local shareholders (3.6111) 
Table 2.4. Descriptive Statistics of Variable of Export Competencies

\begin{tabular}{lcr}
\hline & Mean & Standard Deviation \\
\hline Export-related expertise and skills & 3.3889 & 1.07644 \\
\hline Knowledge of exports & 3.2222 & 1.01731 \\
\hline Implementation of the learning process in organizations & 3.3056 & 1.23796 \\
\hline Ability to find the right intermediaries & 4.2500 & .87423 \\
\hline Ability to promote products & 4.1389 & .79831 \\
\hline Ability to obtain customers & 4.0556 & .75383 \\
\hline Ability to do business planning & 4.2778 & .91374 \\
\hline Ability to manage transportation & 3.8333 & .87831 \\
\hline Ability to make payments & 4.1389 & .83333 \\
\hline Ability to do business with large corporations & 3.9444 & .95452 \\
\hline Ability to manage production time & 3.5556 & 1.08086 \\
\hline Ability to finance activities & 3.5278 & .99960 \\
\hline Ability to meet HR needs & 3.8333 & .84515 \\
\hline Ability to satisfactorily meet consumers' requests & 3.4444 & .87650 \\
\hline Ability to obtain information about the competition & 3.5833 & 1.10518 \\
\hline Knowledge of market & 3.9444 & .75383 \\
\hline Knowledge of regulations & 4.1111 & .70823 \\
\hline Knowledge of legal aspects of international trade & 3.9722 & .77408 \\
\hline Availability of general statistics & 3.7778 & 1.07201 \\
\hline Ability to meet the quota & 3.8889 & .97915 \\
\hline Level of export competencies & 3.8097 & .50509 \\
\hline
\end{tabular}

Table 2.5. Descriptive Statistics of Variable of Export Competencie

\begin{tabular}{lcr}
\hline & Mean & Standard Deviation \\
\hline Quality of product and performance & 3.5833 & 1.07902 \\
\hline Quality of process and performance & 3.5833 & 1.15573 \\
\hline Producing top level products & 3.7222 & 1.08525 \\
\hline Quality of service & 3.8611 & 1.17480 \\
\hline Product innovations & 3.6111 & 1.20185 \\
\hline High range of products & 3.2500 & .76997 \\
\hline Visibility of advertisement and promotion & 3.5000 & .87831 \\
\hline Reputation of advertisement and promotion & 3.6111 & .80277 \\
\hline Knowledge of market & 3.4167 & .99642 \\
\hline Competitive prices & 3.1111 & 1.03586 \\
\hline Low production costs & 3.8889 & .78478 \\
\hline Extensive network of distribution & 3.4444 & 1.08086 \\
\hline Advantages of marketing methods & 3.8056 & .98036 \\
\hline Level of emphasis on implementation of competitive strategy & 3.5684 & .53902 \\
\hline
\end{tabular}

Table 2.6. Descriptive Statistics of Variable of Business Environment

\begin{tabular}{lcr}
\hline & Mean & Standard Deviation \\
\hline Business costs & 3.7222 & .91374 \\
\hline Laws and regulations & 3.5000 & 1.02817 \\
\hline Exchange rate & 3.7500 & 1.10518 \\
\hline Position of balance of payments & 3.8889 & 1.11555 \\
\hline Political conditions & 4.1111 & .91894 \\
\hline Level of product innovation & 3.3889 & .76636 \\
\hline Level of process innovation & 3.5556 & .84327 \\
\hline Time required for product innovation & 3.6944 & .98036 \\
\hline Time required for innovation process & 3.6944 & .92023 \\
\hline level of changes in customers' tastes & 2.8889 & .82038 \\
\hline MEAN of uncertainty of business environment & 3.6194 & .47619 \\
\hline
\end{tabular}

Table 2.7. Descriptive Statistics of Variable of Performance of SMEs

\begin{tabular}{lcr}
\hline & Mean & Standard Deviation \\
\hline Sales to the ASEAN countries & 3.1389 & .83333 \\
\hline Sales to countries beyond ASEAN & 3.0278 & .84468 \\
\hline Reputation of products in ASEAN & 3.1944 & .66845 \\
\hline Reputation of products beyond ASEAN & 3.2778 & .81455 \\
\hline Growth in export performance & 4.2130 & 1.09806 \\
\hline Export profitability compared with that of the competitors & 2.5278 & 1.20679 \\
\hline Level of export performance & 3.1597 & .63570 \\
\hline
\end{tabular}

information from financial institutions (3.5833), and information from the parent company, if the company only exports (3.5278).

Based on Table 2.4. we can conclude that for the variable of export competencies, five items of statements considered important viewed from the mean value given by the respondents are the ability to do business planning (4.2778), the ability to find the right intermediaries (4.2500), the ability to make payments (4.1389), the knowledge of the market (3.9444), and the ability to meet quotas (3.8889).

Table 2.5. shows the average response of respondents towards the level of importance of competitive strategies in their business. Based on the results of descriptive statistical analysis of the competitive strategy variable, five items of statements considered important viewed from the mean value given by the respondents are a low production cost (3.8889), quality of service (3.8611), advantage marketing methods (3.8056), resulting in a top level product (3.7222), and product innovation (3.6111) Table 2.6. shows the average response of respondents to the level of uncertainty of the business environment. Based on the results of descriptive statistical analysis for variable of competitive strategy, the five most important items of uncertainty in the business environment are: political conditions (4.1111), the condition of balance of payments (3.8889), the exchange rate (3.7500), business costs (3.7222) and the time required for product innovation and process (3.69994). 
Table 2.7. shows the mean value response of respondents to the variable of performance of SMEs. Based on the results of descriptive statistica analysis of the variable of performance of SMEs, the item of statement considered to have the highes value is the aspect of growth in export performance (4.2130) and the lowest is the export profitability (2.5278)

\section{Hypotheses Testing}

\section{Testing Hypotheses 1-3}

To test Hypothesis 1 (Hypothesis 1: Export-related information affects export competitive strategy), Hypothesis 2 (Sources of export-related information affect export competitive strategy), and Hypothesis 3 (SMEs' export competencies affect competitive strategy) in this study, a multiple regression mode was used. This model was used to examine the influence of perception of information, information sources, and export competencies on competitive strategy. Calculation in a multiple regression mode will result in parameter estimates with a value of $t$, and the coefficient of determination (R2). If the regression coefficient is significant at $\mathrm{p}<0.05$ it means that the independent variables have a significant influence on the dependent variables.

Regression coefficient indicates the accuracy of the regression line and measures the ability of the mode to explain the variation of dependent variables. The bigger the value of R2, the better the model in explaining the variation of dependent variables. Table 2.8. shows the test results of the influence of perception of information, information sources and export competencies on competitive strategy.

Table 2.8. Test Results of Hypothesis 1-3

\begin{tabular}{|c|c|c|c|c|c|c|c|c|}
\hline $\begin{array}{l}\text { Dep } \\
\text { Var }\end{array}$ & $\begin{array}{l}\text { Para } \\
\text { meter }\end{array}$ & Stand B & SE & $\mathrm{t}$ & Sig & F & Sig & R2 \\
\hline \multirow{4}{*}{ CS } & Constant & - & & 13.960 & . 000 & \multirow{4}{*}{18.478} & \multirow{4}{*}{.000 (a) } & \multirow{4}{*}{.158 } \\
\hline & PI & -.233 & .062 & -3.162 & .002 & & & \\
\hline & SI & -.214 & . 086 & -2.349 & . 019 & & & \\
\hline & EC & .382 & .077 & 4.990 & .000 & & & \\
\hline
\end{tabular}

Remark

Remark
CS: Competitive Strategy; PI: Perception of Information; SI: Sources of Information; EC: Export Competencies and specialized journals, other companies, and industrial associations), institutions (the government offices and publications), internal sources (the databases, employees, sales, branches, overseas missions), and electronic sources (the private, public databases, and internet). For the case of SMEs in Indonesia, this study finds that information adversely affects competitive strategy. Based on the analysis of conditions in Indonesia, SME players tend to avoid risks, so the more information they get, the less wise they are in managing information.

Export competencies (export experience and expertise) have an important role in explaining the capacity of SMEs in using important information and sources of information and also their involvement in export activities. Seringhaus (1993) as cited in Julien and Ramangalahy (2003) argues that the export competencies have an enormous influence on the company's capacity and ability to use information appropriately, when the company must face challenges or wants to benefit from the opportunities to enhance growth and profitability. Results of the research also show that the greater the competence of information, the higher the SMEs' performance. Some competencies a company may have, according to the literature, include international competence, international marketing competence, marketing expertise, and knowledge and skills in export. It is also found in this study that export competencies affect competitive studies. The higher the competencies, the higher the competitive strategy.

\section{Testing Hypothesis 4}

To test the hypothesis 4 (The higher SMEs' export competencies, the greater their competitive Table 2.9. Test Results of Hypothesis 4

\begin{tabular}{ccccccccc}
\hline $\begin{array}{c}\text { Dep } \\
\text { Var }\end{array}$ & $\begin{array}{c}\text { Para } \\
\text { meter }\end{array}$ & B & SE & t & Sig & F & Sig & R2 \\
\hline EP & Constant & & .249 & 13.735 & .000 & .927 & $.337(\mathrm{a})$ & .003 \\
\cline { 3 - 10 } & CS & .056 & .070 & -.963 & .337 & & & \\
\hline Remarks: \\
EP : Export Performance, CS: Competitive Strategy.
\end{tabular}

strategy), this study used a simple regression model. From the calculation of a simple regression model, an estimate parameter with its t-value and coefficient of determination (R2) would be obtained. If the regression coefficient is significan at $\mathrm{p}<0.05$, it means that independent variable have a significant influence on dependent variables. Regression coefficient indicates the accuracy of the regression line and it measures the ability of the model to explain variations in dependen variables. The bigger $\mathrm{R} 2$, the better the mode in explaining variations in dependent variables. Table 2.9 shows the test results of the influence of competitive strategy on export performance. From the test results in this model, it can be concluded that competitive strategy has no influence on SMEs performance.

\section{Testing Hypothesis 5}

To test the hypothesis 4 (environmental uncertainty has moderating impact of competitive strategy on performance), this research used hierarchica regression analysis. This model was used to test the moderating impact of the environmental uncertainty on relationship between competitive strategy and export performance. The calculation would result estimated parameter with its t-value and coefficient of determination (R2). If the regression coefficient is significant at $\mathrm{p}<0.05$, it means that independent variables have a significan influence on the dependent variable. Regression coefficient indicates the accuracy of the regression line and it measures the ability of the model in explaining variations in dependent variables. The bigger the R2 value, the better the model in explaining variation in dependent variables. The moderating impact of the variable of environmental 
Table 2.10. Moderating Impact of Environmental Uncertainty

\begin{tabular}{lccrr}
\hline \multirow{2}{*}{ Variable } & Step 1 & \multicolumn{2}{c}{ Step 2 } & \multicolumn{2}{c}{ Step 3 } \\
\cline { 2 - 5 } & \multicolumn{3}{c}{ Standardized Beta } \\
\hline SK & -.056 & -.065 & $-.113^{*}$ \\
\hline KLB & & .037 & $-.250^{* * * *}$ \\
\hline SK x KLB & & & $.421^{* * * *}$ \\
\hline $\mathrm{R}^{2}$ & .003 & .004 & .091 \\
$\mathrm{R}^{2}$ change & .003 & .001 & .086 \\
F change & .927 & .379 & 28.056 \\
Sig. F change & .337 & .297 & .000 \\
\hline ***: significant at 0.01 & ***: significant at 0.05 & $*:$ significant at 0.1 & \\
\hline
\end{tabular}

uncertainty is seen from the significance of interaction between the independent variable and the moderator, and the significance of changes in $F$ and $R$ 2. Table 2.10 shows the test results of the moderating impact of environmental uncertainty on the relationship between competitive strategy and export performance. From the results, it can be concluded that the uncertainty has a moderating impact on the relationship between competitive strategy moderate and SMEs' performance. The results indicate that the influence of competitive strategy will be greater in an uncertain business environment. An uncertain environment wil encourage companies to explore strategies to improve competitive performance. This is supported by the findings of previous researchers (Skinner, 1969; Hofer, 1975; Van Dierdonck and Miller 1980) which provide evidence that environmental uncertainty is identified as an important contingency in both conceptual and empirical studies in competitive strategy and manufacturing strategy. In this study it is indicated that environmental dynamism will support the decision on options of competitive strategy.

\section{MANAGERIAL IMPLICATIONS}

Several implications are advanced from the outcomes of this research. In Indonesia, there is a lack of empirical research in management of competencies and information of SMEs. This study contributes to the development of a management competency theory by adding to the existing body of literature on the subject. It takes an important step in the direction of the empirical development. This study provides a brief description of the extent of competency and information search by SMEs in fast developing countries such as Indonesia.

This study suggests that for the Indonesian manufacturing firms to survive and to grow, they need not only to improve its competencies but also information search capabilities. The process of acquiring the competencies and informations is not simple and effortless. Developing and maintaining these capabilities require both conscious efforts by the organizations and also support from other institutions and government, in terms of partnership programme and government policy.

This study finds that competencies positively influence the competitive strategy. Thus, Indonesian manufacturing firms should consider increasing the competencies and information search which are currently at low level. Most of the firms in Indonesia are also technically inefficient in using the informations. One of the main reasons for the inefficiency in informations in Indonesia is the misconception of information management. In Indonesian, information is still viewed as resources which are independently able to stand alone in improving the business performance without considering the complementary factors such as human resources (e.g. expertise and skilled workers) and social contexts (e.g. environment conditions, internal and external culture).
The success of managing competencies and informations also depends on top management support. Top management must be ready to make sacrifices and accept failures as well as provide supports by committing visible fund and resources. Top management also should understand factors that drive competencies development. In the case of Indonesia, the following factors are found to be critical for the success of competencies development: (1) top management (support and involvement); (2) culture (openness of innovation, participation, cross functional working system, open communication system); (3) strategy (technology sourcing, monitoring systems); (4) skill development (employee training and education); and (5) resources (availability of finance, material and technocrat).

\section{CONCLUSION}

The research aims (1). to examine the effect of export-related information on SMEs' export competitive strategy, (2). to test the influence of information sources on SMEs' competitive strategy, (3). to test whether the export competencies affect competitive strategy, (4). to examine the effect of competitive strategy on SMEs' export performance (5). to test whether the effect of export competitive strategies on export performace depending on the uncertainty in business environment.

Export competencies have an enormous impact on the company's capacity and ability to use information appropriately, when the company must confront challenges or wants to take the opportunities to enhance growth and profitability. The results of the research also show that the greater the competence of information SMEs have, the higher their performance. Some corporate competence according to the literature includes international competence, international marketing competence, marketing expertise, and knowledge and skills in export. It is also found in this study the export competencies affect competitive studies. The higher the competence, the higher the competitive strategy.
Competitive strategy does not directly affect export performance, but it is because of the moderating impact of uncertainty in business environment. The results indicate that the influence of competitive strategy will be greater in an uncertain busines environment. An uncertain business environmen will encourage companies to explore strategies to improve competitive performance. This is supported by the findings of previous researchers (Skinner 1969; Hofer, 1975; Van Dierdonck and Miller 1980) which provide evidence that environmental uncertainty is identified as an important contingency in both conceptual and empirical studies in competitive strategy and manufacturing strategy. In this study it is indicated that environmenta dynamism will support the decision on options of competitive strategy.

\section{Limitations and Suggestions}

Furthermore, the researcher acknowledges some limitations to this study which may make the results of the study less optimal. There were only few companies involved in this research, so the model and the results cannot create generalization, given the large population of small and medium enterprises (SMEs) in Indonesia. Respondents used a perceptual method in measuring the performance of SMIs, which can lead to bias in the measurement. In addition, from each company there was only respondent participating in this study, that is the manager, so monoreponse bias was very likely to happen. This study was conducted only in one stage without doing a pilot test, leading to less conformity. This study did not include variables such as the role of government, business environment analysis and other contextual factors. The results give few inputs to the local government and SMEs while in a broade scope more inputs based on a broader and deepe analysis are needed.

Some suggestions for further research include:

1. It is necessary to increase the number of respondents in the study, given the large number of SMEs in Indonesia in order that the research results obtained can be generalized. 
2. Future studies may include variables of the role of government, business environment analysis and other contextual factors to determine the effect of each variable on the export performance of SMEs.

3. To reduce a monoresponse bias caused by respondents' biased perception, future studies should use multiple respondents.

4. Researchers should exercise more caution in determining the research samples since most exporting SMEs do not produce their own products. This causes biases on several matters in the evaluation of information and competitive strategies.

\section{REFERENCES}

Anonymous. (2004). Peningkatan Daya Saing Industri Manufaktur.

Butler, A.S. (2000). Developing Your Company's New Business. The Journal of Business Strategy. 21 (3), 13-17.

Crisman, K. (2004). Why should small businesses adopt e-business?. Latitude Consulting Group, Inc.

Cavusgil, S.T. (1984). Changing Nature of Firms International Market Research Activities during The Internationalization Process. In Kaynak E. (ed.), International Marketing Management, (pp. 207-218), New York: Praeger Publishing Company.

Damanpour, F. (2001). E-business E-commerce Evolution: Perspective and Strategy. Managerial Finance, 27 (7), 16-33.

Denis, J.E., \& Depelteau, D. (1985) Market Knowledge, Diversification and Export Expansion. Journal of International Business Studies, 7(1), 77-89.

Ellitan, L. (1998). Pengaruh Sumber Keunggulan Kompetitif terhadap Kinerja Industri Manufaktur di Indonesia, (Unpublished Thesis), Universitas Gadjah Mada, Yogyakarta.

Ghozali, I. (2005). Aplikasi Analisis Multivariate dengan Program SPSS. Edisi 3. Semarang: Badan Penerbit Universitas Diponegoro.

Julien, P.E., \& Ramangalahy, C. (2003). Competitive Strategy and Performance of Exporting SMEs: An Empirical Investigation of The Impact of Their Export Information Search and Competencies. Entrepreurship Theory and Practice, 27 (3), 227-245.

Hair, J.F., Anderson, R.L., Tatham, dan W.C., Black. (1988). Multivariate Data Analysis, $5^{\text {th }}$ (ed.), Upper Saddle River, New Jersey: Prentice Hall, Inc.

Kleinnschmidt, E.J., \& Ross, R.E. (1986). Export Performance and Foreign Market Information. Relation for Small High Technology Firms. Journal of Small Business and Entrepreneurship, 4(1), 14-25.

Phan, D.D. (2001). E-Business Management Strategies: A Business to Business Case Study. Information System Management, Fall, 61-69.

Raharjo, B. (1999). Implementasi Teknologi Informasi di Industri Kecil Menengah. Bandung: Pusat Penelitian Antar Universitas bidang Mikroelektronika(PPAUME) Institut Teknologi Bandung.

Santoso, S., \& Tjiptono, F. (2004). Riset Pemasaran: Konsep dan Aplikasi dengan SPSS. Jakarta: Elex Media Komputindo.

Samice, S., Walters, P.G.P \& Dubois. (1993). Exporting as an Innovative Behavior: An empirical investigation. International Marketing Review, 10 (3), 5-25.

Seringhaus, R. (1993). Comparative marketing behavior of Canadian and Austrian high-tech exporters. Management International Review, 33 (3), 26-36.

Sekaran, U., (2003). Research Method for Business: A Skill-Building Approach. fourth edition. New Jersery: John Wiley and Sons, Inc.

Susilo. Y.S, Sutarta, A.E., Sieroso, A. (2008). Strategi Bertahan Industri Kecil Pasca Kenaikan Harga Pangan dan Energi: Kasus pada Industri Makanan di Kota Yogyakarta. Proceeding from National Seminar of Science and Technology-II 2008. Lampung: University of Lampung.

Suprianto. (2004). Kinerja UKM dalam Kegiatan Ekspor. Jakarta: Direktorat Neraca Produksi, Badan Pusat Statistik.

Tambunan, Mangara. (2004). Tiga Kendala Besar Pengembangan UKM Berorientasi Ekspor. Article from Panel Discussion on Micro Entrepreneurship Development, Jakarta.

Turban, E., Mc. Lean, E. Wetherbe, J. (2005). Information Technolgy for Management: Transforming Organization in the Digital Economy. New York: John Wiley and Sons.

Wang, S., dan Cheung, W. (2004). E-Business Adoption by Travel Agencies: Prime Candidates for Mobile e-business. International Journal of Electronic Commerce. Spring 8(3), 43-63.

www.ekonomi.okezone.com, March 17, 2010.

www.ekonomi.okezone.com, March 23, 2010.

www.ekonomi.okezone.com, April 23, 2010. 